\title{
Long COVID syndrome - general aspects
}

\author{
Sindromul Long COVID - aspecte generale
}

\author{
Adriana TICĂRĂU ${ }^{1,2}$, Mihaela Adela IANCU ${ }^{1,2}$, Dumitru MATEI I,3 \\ ${ }^{1}$ Universitatea de Medicină şi Farmacie „Carol Davila“, Bucureşti, România \\ ${ }^{2}$ Cabinet medical individual, Bucureşti, România \\ ${ }^{3}$ Institutul Naţional pentru Sănătatea Mamei şi Copilului „Alessandrescu-Rusescu“, Bucureşti, România
}

\section{ABSTRACT}

One year after the World Health Organization declared the global pandemic of SARS-CoV-2 (March 2020), growing scientific evidence worldwide suggests that a small percentage of people who have developed COVID-19 and healed after the initial infection may experience a series of persistent symptoms over a period of more than 12 weeks, such as marked fatigue, shortness of breath, confusion, diarrhea, or other symptoms that cannot be explained by an alternative diagnosis. This status has been called "long COVID syndrome" or "post COVID syndrome".
\end{abstract}

Keywords: SARS-CoV-2, COVID-19, long COVID syndrome

\section{REZUMAT}

La un an de când Organizația Mondială a Sănătății a declarat pandemia globală cu virusul SARS-CoV-2 (martie 2020), tot mai multe dovezi ştiințifice descoperite pe plan mondial sugerează că o parte dintre persoanele care au dezvoltat boala COVID-19 şi care s-au vindecat după infecția inițială se pot confrunta cu o serie de simptome persistente pe o perioadă ce depăşeşte 12 săptămâni, precum oboseală marcantă, dificultăți respiratorii, confuzie cerebrală, diaree sau alte simptome ce nu pot fi explicate printr-un diagnostic alternativ. Acest status a fost denumit sindromul Long COVID sau sindromul post-COVID.

Cuvinte cheie: SARS-CoV-2, COVID-19, sindromul Long COVID

\section{INTRODUCERE}

Începem să înțelegem impactul pe termen lung al bolii COVID-19. Un procent mic de persoane care au trecut prin boală au prezentat simptome persistente cu durată de câteva luni, simptome diverse care nu au putut fi încadrate într-un diagnostic alternativ. Mai mulți termeni au fost folosiți pentru a descrie simptomele prelungite după boala COVID-19, cum ar fi "COVID lung", "Sechele postacute ale infecției cu SARS-CoV-2" (PASC), „COVID-19 post-acut", „COVID-19 cronic" și "sindromul post-COVID" [1-4]. Managementul în faza acută a bolii urmărește monitorizarea pacientului, de- tectarea și tratarea complicațiilor acute legate de COVID-19, în timp ce, după ieșirea din faza acută, managementul în cazul unor pacienți necesită evaluare pentru simptome persistente sau noi.

Deși nu există definiții clar acceptate ale etapelor de manifestare a bolii COVID-19, în general se au în vedere următoarele trei categorii care reflectă recuperarea simptomatică și nu sunt legate de infecția virală activă și infectivitatea: COVID-19 acut (simptome ale COVID-19 timp de până la 4 săptămâni după apariția bolii), COVID-19 simptomatic în curs de desfășurare (simptome ale COVID-19 de la 4 la 12 săptămâni după 
debutul bolii) și post-COVID-19 (simptome care se dezvoltă în timpul sau după COVID-19, continuă $\geq 12$ săptămâni, neexplicate printr-un alt diagnostic) [5]. Pentru a veni în sprijinul atât al pacienților, cât și al medicilor, Organizația Mondială a Sănătății a creat o platformă unde se pot raporta cazuri clinice pentru o mai bună înțelegere a spectrului de afecțiuni post-COVID-19 din cadrul acestei infecții virale (global COVID-19 clinical platform case report form).

\section{SIMPTOME}

Cele mai frecvente simptome persistente după COVID-19 includ de obicei oboseală, dispnee, dureri toracice și tuse. Pacienții care se recuperează după COVID-19 pot prezenta, de asemenea, simptome psihologice (anxietate, depresie, sindromul de stres posttraumatic) și cognitive (tulburări de memorie și de concentrare), similare cu sindromul experimentat de pacienții care se recuperează după alte boli, cunoscut sub numele de sindrom de terapie postintensivă [6-9].

Simptomele fizice au fost semnalate în mai multe serii observaționale care descriu manifestări persistente la o treime dintre pacienții care au depășit faza acută a infecției virale cu SARS-CoV-2 și care prezintă mai mult de un simptom. Aceste simptome fizice persistente frecvente includ: oboseală (15-87\%), dispnee $(10-71 \%)$, durere toracică $(12+44 \%)$, tuse $(17-26 \%)$. Simptomele fizice persistente mai puțin frecvente (sub $10 \%$ ) includ anosmie, dureri articulare, cefalee, sindrom sicca, rinită, disgeuzie, inapetență, vertij, mialgii, insomnie, alopecie, transpirație și diaree, neuropatie periferică, greață, erupții cutanate [6-9].

Manifestările psihologice sau cognitive sunt, de asemenea, frecvente post-COVID-19 acut și sunt întâlnite mai frecvent decât la cei care se recuperează după boli similare [10,11]. Într-un studiu efectuat pe 100 de pacienți cu COVID-19 care au fost externați din spital, $24 \%$ au raportat tulburări de stres posttraumatic, $18 \%$ au avut probleme de memorie, iar $16 \%$ au avut probleme de concentrare [10].

De asemenea, există mai multe rapoarte de simptome audio-vestibulare: pierdere a auzului (bruscă și unilaterală), tinitus și vertij rotativ la adulți cu o gamă largă de severitate a simptomelor COVID-19 [12].

Simptomele descrise în mod obișnuit ale sindromului Long COVID (oboseală, tuse, durere toracică, dispnee), care însoțesc și tahicardia ortostatică excesivă, orientează către un diagnostic de sindrom de tahicardie posturală (POTS) post-COVID-19 [13]. De asemenea, au fost raportate cazuri rare de sindrom GuillainBarré (GBS) după COVID-19 [22]. Cu toate acestea, o asociere cauzală potențială a COVID-19 cu riscul de GBS rămâne incertă. Un studiu de cohortă din Regatul Unit nu a reușit să arate o asociere specifică între infecția cu GBS și COVID-19 [23].
Studiile care descriu rezultatele pe termen lung pentru copiii cu COVID-19 lipsesc și riscul apariției simptomelor persistente sau recurente este neclar. Într-o cohortă de 171 de copii care au fost testați pozitiv pentru SARS-CoV-2, $5 \%$ au avut formă moderată, $58 \%$ au avut boală ușoară și $36 \%$ au fost asimptomatici. Dintre cei 151 de copii care erau disponibili pentru urmărire la trei până la șase luni, simptomele COVID-19 postacute au apărut la 12 , toți fiind simptomatici la momentul diagnosticului. Doi copii au dezvoltat afecțiuni inflamatorii postacute (MIS-C); la restul de 10 copii, simptomele postacute s-au remediat în decurs de opt săptămâni și au inclus tuse ușoară, oboseală sau ambele [25]. Urmărirea continuă a copiilor cu COVID-19 este necesară pentru a defini mai bine rezultatul pe termen lung.

\section{DURATĂ}

Numeroase studii clinice au demonstrat că $10 \%$ dintre pacienții diagnosticați cu COVID-19 prezintă simptome persistente după infecție timp de încă o lună, iar 1,5-2\% dintre pacienți pot prezenta simptome până la trei luni după boală [25].

În cadrul unui studiu condus de Universitatea din Leicester, care a urmărit cu puțin peste 1.000 de pacienți care au avut nevoie de spitalizare pentru COVID, s-a constatat că majoritatea (7 din 10) nu și-au revenit complet nici la cinci luni după ce au fost externați. Dintre cei care lucrau înainte de îmbolnăvire, 17,8\% nu mai lucrau și încă $19,3 \%$ au prezentat o schimbare a sănătății în munca lor. Alte studii indica faptul că sunt necesare 12 luni pentru remiterea simptomelor, incluzând atât pacienții care nu au avut nevoie de spitalizare, cât și cei care au avut [14]. Într-un alt studiu, aproape $40 \%$ dintre pacienți nu au reușit să se întoarcă la activități normale la 60 de zile de la externare [15].

La pacienții cu formă ușoară, datele sugerează, de asemenea, că o proporție semnificativă poate prezenta simptome până la câteva luni, dacă nu mai mult [16].

Unele simptome se rezolvă mai repede decât altele. De exemplu, febra, frisoanele și simptomele olfactive/ gustative se rezolvă de obicei în decurs de două până la patru săptămâni, în timp ce oboseala, dispneea, disconfortul toracic, deficiențele cognitive și efectele psihologice pot dura câteva luni (două până la șase luni) [17]. Mai multe studii au examinat recuperarea simptomelor olfactive și gustative la pacienții cu COVID-19. Majoritatea au recuperare completă sau aproape completă la o lună după boala acută, deși în unele studii aceste simptome au persistat mai mult. Pacienții cu hiposmie și pacienții de sex masculin se pot recupera mai rapid în comparație cu cei care au anosmie sau sunt de sex feminin $[18,19]$. 


\section{PREDISPOZITुIE}

Persoanele în vârstă, femeile și cei care au avut cinci sau mai multe simptome în prima săptămână de îmbolnăvire cu COVID-19 au mai multe șanse de a dezvolta sindromul long COVID. Afectează aproximativ $10 \%$ dintre tinerii cu vârste cuprinse între 18 și 49 de ani care au suferit de COVID-19, crescând la $22 \%$ din persoanele cu vârsta peste 70 de ani. Persoanele cu astm au fost, de asemenea, mai susceptibile de a dezvolta acest sindrom [14].

Dintre pacienții spitalizați cu COVID-19, aproximativ 10-20\% necesită respitalizare în decurs de 30-60 de zile $[20,21]$. Factorii de risc pentru respitalizare au inclus vârsta peste 65 ani sau prezența uneia sau mai multor comorbidități (BPOC, insuficiență cardiacă, diabet zaharat cu complicații, boală cronică de rinichi, obezitate $I M C \geq 30 \mathrm{~kg} / \mathrm{m}^{2}$ ) [20].

Într-un alt studiu, aproape $40 \%$ dintre pacienți nu au reușit să se întoarcă la activitățile normale la 60 de zile de la externare [15].

\section{EVALUAREA PACIENTTILOR CU SINDROM LONG COVID}

Ghidurile pentru evaluarea pacienților care prezintă acest sindrom sunt încă în lucru. Mai multe centre mari au creat clinici post-COVID-19 care oferă o abordare multidisciplinară a evaluării și managementului prin urmărirea pacienților cu afecțiuni noncritice. Aceste centre utilizează măsuri multiple de screening, inclusiv evaluarea cognitivă, scala de anxietate și depresie, pe lângă abordarea terapeutică, reabilitare și testarea funcției pulmonare [26].

\section{TRATAMENT}

În prezent, nu există tratament specific. Dar recunoașterea acestui sindrom este un pas cheie către căutarea unui tratament țintit [27].

Terapia se concentrează pe tratamentul specific al simptomelor persistente, cum ar fi oboseala, sechelele respiratorii sau tulburările cognitive. Managementul constă în abordarea interdisciplinară, gestionarea comorbidităților, urmărirea de rutină în cadrul unor clinici dedicate îngrijirilor post-COVID, acolo unde ele sunt disponibile.

\section{CONCLUZII}

Deși definiția pare să evolueze și încă nu este finalizată, în prezent recunoaștem PASC sau sindromul Long COVID dacă simptomele cauzate de infecția cu SARS-CoV-2 persistă mai mult de 28 de zile.

Există limitări semnificative în eforturile de cercetare pentru a înțelege istoria naturală a unei pandemii care are doar puțin peste un an. Luând în considerare observațiile din focarele SARS și MERS determinate tot de coronavirusuri, clinicienii anticipează o gamă similară de efecte pe termen lung care constau în oboseală, rezultate anormale ale funcției respiratorii sau prevalență crescută a afecțiunilor psihice.

În lipsa unui tratament etiologic, obiectivele principale ale abordării terapeutice includ gestionarea comorbidităților, reabilitarea pulmonară și urmărirea continuă multidisciplinară care vizează recunoașterea deficiențelor și îmbunătățirea rezultatelor.

Eforturile comunităților medicale și științifice se concentrează pe înțelegerea și tratamentul sindromului Long COVID, prioritate pentru sănătatea publică.

\section{REFERENCES}

1. Del Rio C, Malani PN. COVID-19-New Insights on a Rapidly Changing Epidemic. JAMA. 2020 Apr 14;323(14):1339-1340.

2. Greenhalgh $T$, Knight M, A'Court $C$, Buxton $M$, Husain L. Management of post-acute covid-19 in primary care. BMJ. 2020 Aug 11;370:m3026.

3. Rubin R. As Their Numbers Grow, COVID-19 "Long Haulers" Stump Experts. JAMA. 2020 Oct 13;324(14):1381-1383.

4. NIH launches new initiative to study "Long COVID". Available at: https://www.nih.gov/ about-nih/who-we-are/nih-director/ statements/nih-launches-new-initiativestudy-long-covid (Accessed on February 26, 2021).

5. COVID-19 rapid guideline: managing the long-term effects of COVID-19. Available at: https://www.nice.org.uk/guidance/ng188 (Accessed on December 21, 2020).

6. Carfi A, Bernabei R, Landi F; Gemelli Against COVID-19 Post-Acute Care Study Group. Persistent Symptoms in Patients After Acute COVID-19. JAMA. 2020 Aug 11;324(6):603-605.

7. Xiong Q, Xu M, Li J, Liu Y, Zhang J, Xu Y, Dong W. Clinical sequelae of COVID-19 survivors in Wuhan, China: a single-centre longitudinal study. Clin Microbiol Infect. 2021 Jan;27(1):89-95.

8. Wong AW, Shah AS, Johnston JC, Carlsten C, Ryerson CJ. Patient-reported outcome measures after COVID-19: a prospective cohort study. Eur Respir J. 2020 Nov 26;56(5):2003276

9. Nehme M, Braillard O, Alcoba G, Aebischer Perone S, Courvoisier D, Chappuis F,
Conflict of interest: none declared Financial support: none declared 
13. Goldstein DS. The possible association between COVID-19 and postural tachycardia syndrome. Heart Rhythm. 2021 Apr; 18(4):508-509.

14. Long Covid: the symptoms and tips for recovery. Available at: https://www.bhf.org. uk/informationsupport/heart-mattersmagazine/news/coronavirus-and-yourhealth/long-covid.

15. Chopra V, Flanders SA, O'Malley M, Malani AN, Prescott HC. Sixty-Day Outcomes Among Patients Hospitalized With COVID-19. Ann Intern Med. 2021 Apr; 174(4):576-578.

16. Havervall S, Rosell A, Phillipson M, Mangsbo SM, Nilsson P, Hober S, Thålin C. Symptoms and Functional Impairment Assessed 8 Months After Mild COVID-19 Among Health Care Workers. JAMA. 2021 May 18;325(19):2015-2016.

17. Halpin SJ, Mclvor C, Whyatt G, Adams A, Harvey $\mathrm{O}$, et al. Postdischarge symptoms and rehabilitation needs in survivors of COVID-19 infection: A cross-sectional evaluation. J Med Virol. 2021 Feb; 93(2):1013-1022.

18. Kosugi EM, Lavinsky J, Romano FR, Fornazieri MA, Luz-Matsumoto GR, Lessa MM, Piltcher OB, Sant'Anna GD. Incomplete and late recovery of sudden olfactory dysfunction in COVID-19. Braz J Otorhinolaryngol. 2020 Jul-Aug; 86(4):490-496.

19. Meini S, Suardi LR, Busoni M, Roberts AT, Fortini A. Olfactory and gustatory dysfunctions in 100 patients hospitalized for COVID-19: sex differences and recovery time in real-life. Eur Arch Otorhinolaryngol. 2020 Dec;277(12):3519-3523.

20. Lavery AM, Preston LE, Ko JY, Chevinsky JR, DeSisto CL, Pennington AF, et al. Characteristics of Hospitalized COVID-19 Patients Discharged and Experiencing Same-Hospital Readmission - United States, March-August 2020. MMWR Morb Mortal Wkly Rep. 2020 Nov 13;69(45):1695-1699.

21. Anesi GL, Jablonski J, Harhay MO, Atkins $\mathrm{JH}$, Bajaj J, Baston C, Brennan PJ, et al. Characteristics, Outcomes, and Trends of Patients With COVID-19-Related Critical IIIness at a Learning Health System in the United States. Ann Intern Med. 2021 May;174(5):613-621.

22. Fragiel $M$, Miró $O$, Llorens $P$, Jiménez $S$, Piñera P, Burillo G, Martín A, et al.; SIESTA (Spanish Investigators in Emergency Situations Team) network. Incidence, clinical, risk factors and outcomes of Guillain-Barré in COVID-19. Ann Neurol. 2021 Mar;89(3):598-603.
23. Keddie S, Pakpoor J, Mousele C, Pipis M, Machado PM, Foster M, et al. Epidemiological and cohort study finds no association between COVID-19 and Guillain-Barré syndrome. Brain. 2021 Mar 3;144(2):682-693.

24. Say D, Crawford N, McNab S, Wurzel D, Steer A, Tosif S. Post-acute COVID-19 outcomes in children with mild and asymptomatic disease. Lancet Child Adolesc Health. 2021 Jun;5(6):e22-e23.

25. Sleat D, Wain R, Miller B. Long COVID: Reviewing the Science and Assessing the Risk. Available at: https://institute.global/ policy/long-covid-reviewing-science-andassessing-risk.

26. Penn Medicine Post-COVID Assessment and Recovery Clinic. Available at: https:// www.pennmedicine.org/for-health-careprofessionals/for-physicians/covidinformation/post-covid19-assessment-andrecovery-clinic-at-penn.

27. Vehar S, Boushra M, Ntiamoah P, Biehl M. Post-acute sequelae of SARS-CoV-2 infection: Caring for the 'long-haulers'. Cleve Clin J Med. 2021 May 3;88(5):267-272. 